\title{
Determinants of Employees Outstanding Performance in Public Corporations: Strategic Human Resource Management Perspectives of Organisational Development and Sustainability
}

\author{
Abdul Amid Aziz Jalloh, Feng Ming
}

\begin{abstract}
Performance management is a strategic component of organisations operationswhich requires careful assessment of its constituents. Success of every institution is determined by its performance management system which ensures the provision of adequate tools that enhances outstanding performance. This study examined determinants of employee outstanding performance in corporate institutions with strategic human resource management perspectives of organisational development and sustainability. In this regard, the study critically reviewed pieces of literature published on issues relating to employee performance, which facilitated the discoveryof great concerns of exceptional performance. In order to addressgaps identified, the study employed descriptive quantitative and correlational methods which facilitated the gathering, classification and presentation of data that led to descriptive analysis, discussions and objective conclusion of the study. Nevertheless;obtaining first-hand information was enhanced through the distribution of 300 questionnaires to sample units. Data obtained from sample units was analysed, using Descriptive statistics and Persian correlation. Processed data shows the significance of training and employee development as key element towards improving performance in several facets of organisational operations. However, further facts discoveredestablished that, high employee engagement facilitate effective employer-employee relationship,which shows motivational values and employees worth that prompt institutions workforce todemonstrate commitment towards organisations success. In addition, financial reward was classified as the principal motivator and its judicious use,emphasised by respondents, could influence employees towards exceptional performance.Persian Correlation established significant relationships described thus: Institutions with efficient performance management systems ensures staff capacity building which increasesemployees'competency level.On the other hand, effective engagement and allocation of financial and no-financial rewards generate an outstanding workforce that leads to organisational development and competitive advantage. In consideration to the foregoing facts, this study is significant to human resource management specialists, training and development consultants and corporate institutions in Sierra Leonne.
\end{abstract}

Key words: Determinants, Employee Outstanding Performance, Public Corporations, Strategic Human Resource Management, Organisational Development, Sustainability.

Revised Manuscript Received on September 13, 2020.

*Corresponding Author

Abdul Amid Aziz Jalloh,* PhD Scholar: School of Economics and Business Administration, Chongqing University- China. Email: azizhrmjay@gmail.com

Professor Feng Ming, School of Economics and Business Administration, Chongqing University- China. Email:fengming@cqu.edu.cn

(c) The Authors. Published by Blue Eyes Intelligence Engineering and Sciences Publication (BEIESP). This is an open access article under the CC BY-NC-ND license (http://creativecommons.org/licenses/by-nc-nd/4.0/)

\section{INTRODUCTION}

Outstanding performance has been the drive ofmany corporations in the world, ranging from small and medium to large scale enterprises. However, corporations in Sierra Leone have demonstrated concerns about staff performance and how suitable motivating tools can be employed to address challenges encircling high-class performance.Identifying causes of exceptional performance is a critical sensation which modelled numerous challenges in corporate organisations. Pelin et al (2015), Muhammad et al (2019) \&Xhavit et al (2018)conducted related research on factors influencing staff performance,focusing on training and development as organisational tool that influencesperformance. They established that, achieving predetermined objectives is a challenge for the growth and sustainability of numerous corporate institutions which has led to competitive drawbacks.

This study however seeks to assess determinants of institutions workforce performance from an outstanding perspective which leads to organisational development and sustainability. In this vein, it therefore carefully examine the following components as machineries which triggers outstanding performance: staff capacity building, financial and non-financial rewards and employee engagement.Several research houses have established that, employee performance is influenced by several organisational factors (Armstrong 2010, Coens and Jenkins 2002\&Brown 2010). Even though individual performance can be influenced by structures dynamics and also person's inducement, which includes organisations commitment to support employees and external causes beyond organisations control (Armstrong2009, Verweire and Berghe 2004 \& Kondalker 2007), individual performance is frequently determined by the system in which the work is done rather than by the personality's creativity, abilities, and efforts (Mullins 2005, Dresner 2008 \&, Armstrong 2010).Forwardlooking performance management process is mainly focusing on increasing employees' capacity to deliver sustained high performance (Scheer et al 2006,Deming 1986\&Noe 2010). Reflecting on previous performance indicators and taking necessary actions to address short-term performance does not connote the strategic focus of achieving competitive advantage (Gladwell 2008,Armstrong 2007\&Fisher 1997).

Published By:

Blue Eyes Intelligence Engineering

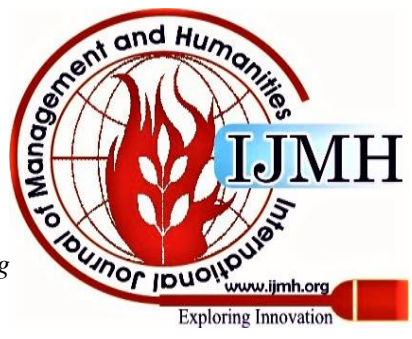




\section{Determinants of Employees Outstanding Performance in Public Corporations: Strategic Human Resource}

Management Perspectives of Organisational Development and Sustainability

An assessment on workers contribution towards organizations performance is not easy, but evidence which establish a connection between enterprise performance and people management is increasing (Bruggeman et al 2001,Rae 2000\&Cokins 2009). Managers are confronted with countless ambiguity and unpredictability, which leads to a bigger menace in decision-making since it is imperative on managers to increase human resource efficiency to improve organisations performance (Rothwell 2005,Krausert 2008, Cartwright 2003\&Chandler 2016). In this regard, achieving extraordinary output is determine by workforce knowledge capacity and methods of compensation instituted by an enterprise, in its thrust for competitive excellence (Grundy and Brown 2003,Adams and Jiang 2017\&Adler et al 2016).The intricacies of motivation and circumstance which shows no ready-made solution or solitary response to issues that enthuses workers to exhibit their talents, makes the different philosophies imperative to the manager (Baumann and Bonner 2017, Brown et al 2019, Cappelli and Conyon 2018\& Conyon et al 2019). Nevertheless, effective transformation of the operations of performance management requires the introduction of a new management philosophy which encompasses people, procedures and information technology, combined and improved to accomplish outstanding performance (Cappelli and Tavis 2016\&DeNisi and Murphy 2017). The effectiveness and progressions of performance requires efficient and constant monitoring to identify initial cautionary mechanism and institute improved methods. Differencesamongstindicators is because of structures disparities, which shows that success is not mainly to an individual employee, it also reflects on the context described and its relevance (Giumetti et al 2015, Goler et al 2016, Hair et al 2014\&Hayek et al 2016).Valueadded is characterized as the key pointer of performance which serves as a contributor towards business growth; however, the key facet of attitude is the circumstance in which individual employees find themselves (Herhausen et al 2018, Ikramullah et al 2016\&Iqbal et al 2015). Motivation influences employees' commitment but differs, depending on the circumstance or situation; however, non-training strategies should be selected when performance fissures are triggered by incompetence exhibited in a situation, flawed incentives, or lack of motivation (Johnson and Connelly 2014, Kallio et al 2016\&Karkoulian et al 2016). While performance will likely always demand multiple interpretations, it is not merely abstract notions about desirable ways to reach a better state. In every organization, the concrete determinants of performance are reflected in people, their ideas, and the material resources through which their ideas reach the marketplace (Kock 2015,Maley and Moeller 2014,Meinecke et al 2017\&Mellahi et al 2016). Training as a performance mechanism is being appraised not based on the quantum of questions of deficiencies addressed by training activity in a company; but how learning needs of an enterprise are addressed, behaviours modified and employee performance improved (Meneghel et al 2016\&Merriman 2017). Capacity building as staff empowerment component increases skills and competencies which improve performance level for achieving exceptional results. When organisations policies and strategies include commitment to relevant capacity building programmes, these needs to be converted into practical action (Miner
2015,Muhammad et al 2019 \&Motro and Ellis 2017). Managing employee development does not connote a new approach; rather, it strongly integrates business improvement and analytical methodologies that managers are acquainted with (Pelin et al 2015, Selvarajan et al 2018 \& Singh et al 2018). Numerous causes lead to the application of human performance improvement, of particular importance to the magnitude that capacity building consultants are involved and are scheduled to become human performance enhancement professionals (Skovoroda and Bruce 2017\&Xhavit et al 2018). Combining performance and learning objectives at the initial phases of development does not result to effective learning or performance behaviours either. Learning and employee development is the way in which a business is devoted to developing its workforce, which result to organizational growth; change and achievement that eventually enhances viable business benefit (Dolores and Ernest 2018, Beninato and Ludlow 2016\&Bhavani et al 2015). Modern culture of self-expression, particularly in today's mostly millennial personnel, has produced an unparalleled desire for creativity, autonomy, and fulfilment in the workplace (Blythe 2014\&Boone et al 2014). There are, of cause, countless explanations why institutions cannot meet their performance expectations. The major cause is the incapability of organisations to professionally and effectually describe and establish client (and hence, shareholder) value (Brian et al 2017,Bryson et al 2013\&Bussin and Van 2014). Competencies have direct relevance to an organization and the way it generates economic value. The link between employees' knowledge capacity and organisations method of achieving goals is emphasised by training which accelerates employees' competencies and directly contribute towardsenterprise development (Chay and Norman2003,Mitchelmore and Rowley 2013, Canos-Daros 2013\&Banerjee et al 2015). Corporations succeed because of employees' active involvement in task performance.When organizations provide capacity building facilities for its workforce, it creates a platform for knowledge acquisition, which empower employees with skills and competencies necessary for high-quality performance (Bauer et al 2016Berberoglu and Secim 2015\&Casimir et al (2014).With the foregoing comprehensive overview, this study seeks to prudently examine prescriptions of organisations operations and establish elements that constitute employees outstanding performance which leads to organisational development. Preceding component has established the study overview whilst subsequent elements will carefully review pieces of literature, describe methods of collecting data, analyse, discuss, summarise and conclude this investigation with meaningful contributions towards policy development.

\section{LITERATURE REVIEW}

\section{A. Training and Development and Knowledge Management as Performance Machineries}

Training and development deals with increasing and improving the skills, knowledge, competencies and experiences of an employee through a succession strategy of staff improvement programme.

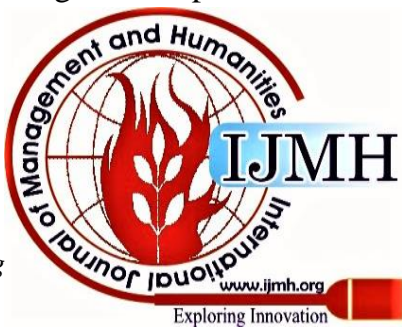


Developmentincreasesemployees' self-fulfilment where their capability at work can be rejuvenated, absorbed and prepared for more obstacles (Obeidat et al. 2014,Lambert et al 2012\&Getnet et al 2014). Development capacitate workers for different positions in organizations and build their career path to move into new jobs in the future. It mainly focus on the expansion of plans to address unexpected occurrences about requirement and responsibilities in job changes (Lamba \& Choudhary 2013,Jehanzeb et al 2013,Swathi 2014\&Majumder (2012). It is essential for managerial staffs to cope with the complexity of organizations technological systems; since it is challenging to train institutions workforce with essential skills and competencies to increase output in modern competitive enterprise (Babu and Reddy 2013,Jehanzeb et al. 2013\&Riaz et al 2013). Previous studies proved that training contributes to intangible outcomes such as higher longstanding self-esteem, which enhances organizational commitment, improves professional competence and eventually influence staff retention and improve organizational efficiency (Chris 1999\&Soltani 2006).

High employee attrition pose serious threat to organizations existence, however, major benefit of training reduces staff turnover and help an organization to retain outstanding staff. Employee development is a modern activity which helps in managing organisations successfully and such can be accomplished if appropriate training measures are administered to the required category of workers (Fathi 2002,Pakdel 2004,Vajehe 2006\&Michaels 2001). Training facilitate the comprehension of institutional values which improves communication among diverse categories of workers. Formulating plans for strategic capacity building activity to enhance human capital development roles includes training needs assessment and design of materials; which supports human resource professionals to develop training programmes, implement such programmes and evaluate their impact on departmental and operational metrics (Majumder 2012,Rumizen 2001,Getnet et al 2014\&Shortliffe 2001).Human capital specialists are required to engage in constant skills development to innovate, practice and monitor several training programmes for employees' development. The preservation and packaging of corporate knowledge is especially relevant today, andthe majority of industries which provide services comprises of knowledgeable personnel (Horibe 1999,Schulz and Jobe 2001,Pollard 2003\&Studt 2003). Knowledge management is an efficient enterprise strategy which involves the classification, selection and arrangement of information that is significant for enterprises to embark on improving workers performance and business competitiveness (Davenport 2002\&Callahan 2004). In the dispensation of business activities, the capabilities of numerous occupations are transferred via apprenticeship. Managing knowledge involves two path-ways, as facts are principally assimilated, processed and stored which leads to packaging and formatting information that suits the desires of employees (Demetrion 2003,Skyrme 2002\&Callahan 2004). Organizations that ensures the distribution of knowledge amongst its workforce is empowered for greater competitive advantage. The result of capacity building provides sustainable competitive advantage strategy for organizations (Becker et al 2001,Collinson and Parcell 2001\&Davenport and Glaser 2002). Such knowledge is an essential asset that has become more significant than property, workforce or capital. Knowledge constitute tacit and explicit; as tacit knowledge serves as information stowed in human intelligence whilst explicit knowledge is confined in brochures and other storage facilities order than human intellect (Callahan 2004,Becker et al 2001\&Mackey and Johnson, 2000). Both types of knowledge are produced through interactions or innovations and such components can be the outcome of effective relationships or alliances. Implicit and explicit information empowers enterprises to act upon different circumstances and evolving challenges (Anderson 2002,Mani 2002). An optimist view of human resource responsibility in managing knowledge is that, HR possess the skills and capacity needed to supervise knowledge (Kuvaas 2006\&Rudman 2003). Given their knowledge of how to facilitate learning and change, human resource practitioners can now move to a more centre stage to manage intellectual capital, challenge existing assumptions and beliefs about the way business and work gets done and also add value by using their knowledge of best practice to help managers address critical issues (Stone 2002\&Williams 2002).

\section{B. Performance Appraisal Strategies for Identifying and Addressing Deficiencies}

Evaluating performance appraisal strengthens management activities and influences institutional performance outcome. It identifies and addressproblems employeesface in their employment activities (Muhammad et al 2019,Xhavit et al 2018\&Pelin et al 2015). Workforce evaluation is a technique employed to assess jobs which are appraised normally regarding time, cost, quantity and quality and it is typically done between supervisors and supervisees (Brown 2010,Armstrong 2010\&Coens and Jenkins 2002). Although it includes numerous advantages for enterprises, performance appraisal has the probability of creating undesirable effect on organizations concerning employees' performance (Verweire and Berghe 2004,Armstrong 2009\&Kondalker 2007). Many employees disapprove of unceasing appraisal procedures and refer them to be an oppressive activity. Performance appraisal regulates, analyse and record information about the comparative value of a worker to an enterprise (Armstrong 2010,Mullins 2005\&Dresner 2008). The parameters, characteristics and standard for appraisal differ, however, essentials of conducting appraisal remains the same. The significance of appraisal for all categories of employees throughout an organization indicate its effective use and determines the success of managing employee performance (Noe 2010,Scheer et al

2006\&Deming 1986).

Published By: 


\section{Determinants of Employees Outstanding Performance in Public Corporations: Strategic Human Resource Management Perspectives of Organisational Development and Sustainability}

Policy regarding staff appraisal should be incorporated in performance management strategy to determine on-going communication to mentor and encourage employees (Armstrong 2007Gladwell 2008\& Fisher 1997). Noteworthy considerations regarding implementing employee assessment policy are frequently adhered to, since performance appraisal policy serves as guiding principles towards workers development.However, unsatisfactory assessment principles can adversely influence employee performance (Cokins 2009,Rae 2000\&Bruggeman et al 2001).Modern academic works emphasised the necessity to examine elements that focuses on appraisal and developmental process so that, staff assessment which includes individual and team will principally be grounded on previous performance (Cartwright 2003,Rothwell 2005,Chandler 2016\&Krausert 2008). Assessing employees' capabilities encompasses numerous management functions such as: regulating and documenting personnel tasks and link outcomes of appraisal to pay. Such forms of incentives are classified as pay for performance or performance related pay, where the category of compensation is linked to workers contribution towards organizational goals (Adams and Jiang 2017,Grundy and Brown 2003\&Adler et al 2016).

\section{High Employee Engagement and Commitment for} Effective Work Performance

The philosophy of employee commitment has attracted a proportion of consideration recently. Job satisfaction; motivation and commitment are predominantly substituted in business by engagement since it seems to be more descriptive with face validity (Conyon et al 2019,Baumann and Bonner 2017,Cappelli and Conyon 2018\&Brown et al 2019). Workers commitment has been transformed to a management mantra, which is believe that engaged workers achieve improved task for their employers and promote their enterprises as company of choice (DeNisi and Murphy 2017\&Cappelli and Tavis 2016). Engagement is described as an employee's participation and fulfilment of passion for task execution. Quantum of well-known applied research and consultancy organizations have similarly defined engagement and emphasised the significance of staff discretion as distinguishing feature of engaged employees (Hair et al 2014,Giumetti et al 2015,Hayek et al 2016\&Goler et al 2016). Commitment is attained with effective control of a strong positive culture that ensures the practice of organizational values. Management support to employees' work and well-being, design systems and jobs to enable employees contribute to the full use of their skills and competences, allows effective employee voice and provide appropriate resources, tools and information, leads to effective performance (Ikramullah et al 2016,Herhausen et al 2018\&Iqbal et al 2015). Employees show more engagement towards an organisation when they are applauded and commended as outstanding performers. An employee could be found to be experiencing three different levels of engagement. He could be engaged, not engaged or disengaged (Kallio et al 2016,Johnson and Connelly 2014\&Karkoulian et al 2016). Engaged staffs are workers who execute their tasks with a desire to achieve organizations goals whereas disengaged employees exhibits unhappiness which makes their unpleasant disposition affects their commitment and human relations (Maley and Moeller 2014,Mellahi et al 2016,Kock 2015\&Meinecke et al 2017). An unengaged employee is one who is seen to be participating but not with passion and energy towards achieving organizations common goal (Merriman 2017\&Meneghel et al 2016). Engagement is discovered to encompass three different facets such as: intellectual engagement which refers to dedication towards performing better at one's job, affective engagement which connotes feeling positive after executing a task and social engagement which involves deliberations with colleagues about improving job associated duties (Motro and Ellis 2017, Miner 2015\&Muhammad et al 2019). Leadership of entrepreneurial firms needs to be strategic in its dealings with workforce engagement as such action leads to effective job performance and organisational growth.

D. Compensation and Rewards as Motivating Mechanisms for Exceptional Job Performance

The incentive structure is a central and integrated feature of the approach to human resources management.The reward structure includes a system of performance valuation of personnel, since the classifying structure plays significant part in the determination of various rewards (Selvarajan et al 2018,Pelin et al 2015\&Singh et al 2018). Incentive is debatably the most critical influences on the eminence and efficient workforce. In almost allphases of enterprises operatives,compensation shapes employee behaviour and organizational effectiveness (Xhavit et al 2018\&Skovoroda and Bruce 2017).Organisationsstandpoint note that, it is virtually obvious that if incentives are administered well, other managerial principles and processes can experience their anticipated effects (Bhavani et al 2015,Dolores and Ernest 2018\&Beninato and Ludlow 2016).The design and application of reward systems cannot only influence employee enthusiasm, but also harness the improvement of safety, value, and creativeness, innovate ideas and countless other results in a successful work environment (Boone et al 2014\&Blythe 2014). When incentives are effective in encouraging improved performance, they can be used to motivate other desired behaviours as well (Bussin and Van 2014\&Brian et al 2017). Rewards are classified as maximum organisational elements and the main driving force that compensate and motivate employees for their work, whichdirectly impacts on the living conditions of personnel, sustain the employment relationship and instils good interpersonal relationships (Bryson et al 2013). Organizations need to attract high-class performers who demonstrate expertise and contribute to successful business operations. However, attracting workers with favourable qualifications is conditioned by the availability of asuitable reward system (Banerjee et al 2015, Chay and Norman 2003\&Canos-Daros 2013).

Published By: 
In order to allow work stability and successful performance, it is necessary not only to provide attraction but also retain high-quality employees (Mitchelmore and Rowley 2013). Reward system motivates workers to exhibit the best of their abilities which enable organisations to retain them for direct positive impact on decreasing fluctuation percentage. The minimum pay, cost of overtime job, benefits and other reward elements are essentially determined by a number of regulations that corporate organisations should take into consideration (Berberoglu and Secim 2015,Casimir et al 2014\&Bauer et al 2016). Organisational rewards must be linked to work performance to achieve better or improved organizational results since trained and qualified employees are retained for effective and efficient performance which propels viable business advantage (Lambert et al 2012,Obeidat et al. 2014\&Getnet et al 2014).

\section{METHODS}

\section{A. Research Design}

Research design is a structure or design for organising a business research project in an efficient manner; which outlines the processes necessary for collection, measurement, and analysis of information which helps the researcher to structure or solve business research problems (Sreejesh et al 2014\&Gubbi et al 2015). This Study used descriptive quantitative survey and correlational method of research which includes gathering, classification and presentation of data. This research method is appropriate for the assessment of determinants of outstanding performance in public corporations, since it is a valuable component that reveals facts relevant for scientific examination and judgement.

\section{B. Research Area}

This research was conducted in the capital city of Sierra Leone (Freetown) focusing on examining operations of three strategic public corporations namely: National Social Security and Insurance Trust (NASSIT), National Revenue Authority (NRA) and the Central Bank of Sierra Leone (BSL). These institutions have been existing for decades and have contributed immensely towards the growth of many government structures.

\section{Sampling of Respondents (Probability Sampling)Sample Size, Sampling Technique}

Sample should be selected from an entire population since it is impracticable for one to collect data from awhole population. This is practically significant particularly when the research process uses interviews, questionnaires, observations or some other data collection techniques. Depending on the circumstance or case studies used, one might be able to collect data from two or three organisations (Winerip 2013Y1ld1z et al 2014,Youngsang and Robert 2013\&Yousefi et al 2016). Each case selected from a population using probability sampling is known which shows a likelihood that all cases within such frame equally have the chance of been understood clearly. (Zafar 2015,Zhao and Liu 2015\& Zeffane et al 2017). This investigation employed probability sampling procedure because it was deemed to be more suitable for this endeavour.This shows that, there is a possibility to respond to research questions accurately to achieve the objectives required to strategically estimate the features of the population from the sample drawn. Therefore, probability sampling is frequently linked to survey and experimental research approaches (Života et al 2017Zwick 2015\&Dineen and Williamson 2012).Statisticians have established that, the bigger the size of a sample selected, the better and more thoroughly its distribution to the normal distribution in a robust manner The sample size selected is governed by the level of assurance that the characteristics of data collected, represents the total population (Gomes-Mejia et al 2012,Giangreco et al 2012\&Gupta and Upadhyay 2012).This study used a sample size of 300 employees from three public institutions, ranging from nonsupervisory to management cadres.Selecting appropriate sampling techniques depends on one's research questions and objectives (Vomberg et al 2015). The size of sample needed and structure of sampling frame and sampling technique may influence one's decision in a research processHowever, simple random sampling provides a selection that is evenly dispersed throughout the population being studied over few hundred cases (Vinesh 2014,Vohra and Seethapathy 2014\&Wang et al (2014). Therefore,this study used a simple random sampling for objective selection of a sample size which enabled the process to select sample units range from managerial to non-managerial employees.

\section{Research Instruments}

Since this study is descriptive in nature, the instrument used in data collection is a survey questionnaire (Venkatesan 2017). Certain kinds of information such as the opinions and assertiveness of workers are best reached by administering survey forms to persons. Such data collected for survey from the real place of incidence of occasions are called primary data (Vimala et al 2015,Shrivastava et al 2015\&Seyyed et al 2013).This research circulated 400 questionnaires across the three institutions; however, 300 filled questionnaires were retrieved which classified respondents as 170 male with $56.5 \%$ and 130 female participants which shows $33.5 \%$. Sample selected in this study served as satisfactory representative sample for organisations selected as case studies. Key elements examined to establish determinants of performance were derived from different research undertakings. However, staff capacity building was anchored on Lambert et al (2012), Obeidat et al. (2014) \&Getnet et al (2014); whilst performance appraisal was adopted from Xhavit et al (2018), Muhammad et al (2019) \&Pelin et al (2015) Nevertheless,workforce engagement and commitment was obtained from William (2002), Conyon et al (2019) \& Baumann and Bonner (2017) and rewards and compensation emanated fromPelin et al (2015)Singh et al (2018)Selvarajan et al (2018). In answering the questionnaires, the five point Linkert scale was used with the following responses 5=Strongly Agree, 4=Agree, 3=Neutral, 2=Disagree, $1=$ Strongly Disagree

Published By: 


\section{Determinants of Employees Outstanding Performance in Public Corporations: Strategic Human Resource Management Perspectives of Organisational Development and Sustainability}

\section{E. Data Analysis}

Chari and Dixit (2015) note that, after data have been collected, they are then managed to allow computerized data entry for statistical analysis. Chittoor et al (2015) emphasised that, these processes must be done both prior to, and immediately following data input to check its accuracy and quality. Colli and Colpan (2016) indicated that, initial data analyses are performed to examine assumptions underlying the data, to gain descriptive data, and to help determine the property of the measures. As noted by Rinallo et al (2017), data should be edited, especially when they relate to answers to flexible questions of interviews and questionnaires, or unstructured observations; which Gaur et al (2014) stated that, from various perspectives, evidence gathered by the questioner, viewer, or scholar in an urgency manner must be evidently interpreted which might be coded analytically in its totality. The modified data must be distinguishable for unique evidence to be accessible in case of any misgivings later (Le et al 2014). Data were gathered from sample units drawn as representative sample and was analysed using descriptive statistics and correlation. Analysis and description established quantum of relevant information regarding factors influencing performance in organisations. Correlation of elements showed significance at 0.1 level (2tailed) between performance management and staff capacity building, engagement and rewards and also between performance and compensation

\section{RESULTS AND DISCUSSIONS}

Table 1: Descriptive Statistics on the distribution of respondents concerning performance and training and

\begin{tabular}{|c|c|c|c|c|c|c|c|c|c|}
\hline & \multirow{4}{*}{$\begin{array}{c}\mathrm{N} \\
\text { Statisti } \\
\mathrm{C}\end{array}$} & \multicolumn{5}{|c|}{ development } & \multirow{4}{*}{$\begin{array}{l}\text { Variance } \\
\text { Statistic }\end{array}$} & \multirow{3}{*}{\multicolumn{2}{|c|}{ Kurtosis }} \\
\hline & & & Minimu & Maximu & & & & & \\
\hline & & Range & $\mathrm{m}$ & $\mathrm{m}$ & Mean & Deviation & & & \\
\hline & & & Statistic & Statistic & Statistic & & & Statistic & $\begin{array}{l}\text { Std. } \\
\text { Error }\end{array}$ \\
\hline OOFPMS & 300 & 1 & 1 & 2 & 1.60 & .491 & .241 & -1.844 & .281 \\
\hline HLPRR & 300 & 1 & 1 & 2 & 1.67 & .472 & .223 & -1.505 & .281 \\
\hline TSSDO & 300 & 1 & 1 & 2 & 1.67 & .472 & .223 & -1.505 & .281 \\
\hline PPDQC & 300 & 1 & 1 & 2 & 1.57 & .496 & .246 & -1.940 & .281 \\
\hline RBAPPF & 300 & 1 & 1 & 2 & 1.60 & .491 & .241 & -1.844 & .281 \\
\hline TIEML & 300 & 1 & 1 & 2 & 1.60 & .491 & .241 & -1.844 & .281 \\
\hline TIEKSC & 300 & 1 & 1 & 2 & 1.60 & .491 & .241 & -1.844 & .281 \\
\hline EDLOP & 300 & 1 & 1 & 2 & 1.67 & .472 & .223 & -1.505 & .281 \\
\hline TIEPL & 300 & 1 & 1 & 2 & 1.60 & .491 & .241 & -1.844 & .281 \\
\hline TPIEE & 300 & 1 & 1 & 2 & 1.57 & .496 & .246 & -1.940 & .281 \\
\hline $\begin{array}{l}\text { Valid N } \\
\text { (listwise) }\end{array}$ & 300 & & & & & & & & \\
\hline
\end{tabular}

Establishing determinants of employees' outstanding performance warranted the gathering of information from sample units in three corporate institutions which revealed several facts through views and opinions expressed by respondents with the aid of survey questionnaires. This study used a sample of 300 respondents from three corporate institutions whose designations range from Technical/clerical and Supervisory to Managerial and Professionals positions. Analysis of data obtained from respondents showed that, organisations operate formal and efficient performance management systems, which makes provision for the recognition and reward of high level of performance. It further shows that being efficient operating systems also support staff development opportunities to ensure retention of high-class performers. Additional facts disclosed that, when problems regarding performance are identified, they are quickly acted upon and dealt with appropriately to prevent unexpected circumstances. As a result of maintaining a structured system, ratings of employees are done based on actual performance and not on authorities or supervisors personal feelings. This is to prevent resentment and grudges which may lead to unhealthy relationship between supervisors and supervisees. Numerous responses from respondents established that staff development is one the factors that increases employee motivation level for effective job performance. This shows that, constant engagement of employees on capacity building stimulate them for excellent performance. However, it was also established that, developing employees' skills and competencies rest on an effective and efficient training programme which ensures the selection of appropriate training methods and hiring of training professionals for effective delivery of training contents. Being that maintaining outstanding performance is a challenging factor, facts disclosed, laid emphasis on training significance as it increases employees' creative acumen which leads to outstanding performance that facilitate organisational development and sustainability.

Published By:

Blue Eyes Intelligence Engineering

\& Sciences Publication

(C) Copyright: All rights reserved.

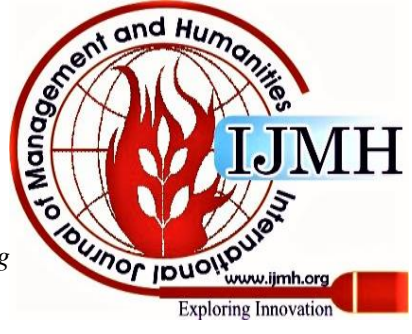


Increasing employees' productivity level was also ascertained by greater responses from sample units which established that, the efficiency level of a training programme accelerate staff productivity level.

Therefore, determining the efficiency level of employees is not measured by reasoning but by exhibition of one's competencies that ensures achievement of organisations strategic objectives. Further emphasis are that, training increases employees efficiency level of performance. The foregoing facts derived from survey have made it clear that, even though there could be several factors that influence exceptional performance, training also serve as a strategic element that increases employees' knowledge capacity for excellent performance.

Table 2: Descriptive Statistics on the distribution of respondents regarding employee engagement and commitment and rewards and compensation

\begin{tabular}{|c|c|c|c|c|c|c|c|c|c|}
\hline & Statistic & Range & Minimum & Maximum & Mean & $\begin{array}{c}\text { Std. } \\
\text { Deviation }\end{array}$ & Variance & Kurtosis & $\begin{array}{l}\text { Std. } \\
\text { Error }\end{array}$ \\
\hline TOPOCD & 300 & 1 & 1 & 2 & 1.57 & .496 & .246 & -1.940 & .281 \\
\hline ACSD & 300 & 1 & 1 & 2 & 1.60 & .491 & .241 & -1.844 & .281 \\
\hline OPTEJP & 300 & 1 & 1 & 2 & 1.53 & .500 & .250 & -1.995 & .281 \\
\hline EIP & 300 & 1 & 1 & 2 & 1.60 & .491 & .241 & -1.844 & .281 \\
\hline EEEEM & 300 & 1 & 1 & 2 & 1.67 & .472 & .223 & -1.505 & .281 \\
\hline ESELOP & 300 & 1 & 1 & 2 & 1.67 & .472 & .223 & -1.505 & .281 \\
\hline OORBP & 300 & 1 & 1 & 2 & 1.57 & .496 & .246 & -1.940 & .281 \\
\hline ERGWP & 300 & 1 & 1 & 2 & 1.53 & .500 & .250 & -1.995 & .281 \\
\hline ERCSIP & 300 & 1 & 1 & 2 & 1.47 & .500 & .250 & -1.995 & .281 \\
\hline FREIEML & 300 & 1 & 1 & 2 & 1.53 & .500 & .250 & -1.995 & .281 \\
\hline FMPM & 300 & 1 & 1 & 2 & 1.67 & .472 & .223 & -1.505 & .281 \\
\hline CIEP & 300 & 1 & 1 & 2 & 1.56 & .497 & .247 & -1.947 & .281 \\
\hline Valid N (listwise) & 300 & & & & & & & & \\
\hline
\end{tabular}

Achieving desires of this study and attaining propositions regarding the subject matter encompasses considerable elements such as staff capacity building discussed in table 1 . Table 2 outlines the contribution of high employee engagement and commitment and the influence of financial and non-financial rewards towards employees' outstanding performance. It was established by facts revealed from survey data that, to guarantee the increase of competencies, organisations provide opportunities for career advancement to ensure high level performers are retained for competitive excellence. The adequacy for skills development was firmly supported by respondents who noted that organisations adequately support employees' skills development programmes for effective job performance. Engaging employees in order to get the best from them is quite challenging; however certain mechanisms or strategies employed will definitely unearth the realities of such engagements. In this regard, information obtained from respondents established that providing necessary tools for effective performanceempowers employees to be diligent in the execution of their duties. Increase in productivity level requires several considerations as the development and sustainability or organisations rest on results achieved. In this regard, respondents noted that effective employee engagement increases productivity level of institutions workforce. In addition, it was also established that continuous staff engagement enhances employee motivation which probably facilitate outstanding performance that leads to institutional growth and sustainability of operations. Allocation of rewards serves as a principal concern towards influencing staff performance since a larger percentage of the workforce principally focus on financial resources as strategic motivating tool for effective job performance. It was categorically established that organisations offer rewards based on performance which made it clear that employees are recognised for good work performance. Daily organisational activities requires innovative competencies to accelerate its operations towards stated objectives. However, ascertaining such facts warrants a diligent workforce that is recognised for creative suggestions that improves performance. Results showed that employees in the three corporate institutions are recognised for brilliant suggestions made during task, adaptive and contextual performance. Organisations normally hold annual events to appreciate employees with immense contribution towards sustainable growth. In this regard, respondents strongly supported that annual recognition events increases employee motivational values. Considering the controversial theory about the principal motivator in organisations operations, respondents established that financial resources serves as the ultimate motivating tool towards exceeding performance targets. In consideration towards factors influencing workforce performance, it was established that compensation influences employee performance. The foregoing has made it clear that employing effective engagement mechanisms and rewarding employees appropriately enhances outstanding performance.

Table 3: Correlations between performance and rewards and also between engagement and rewards

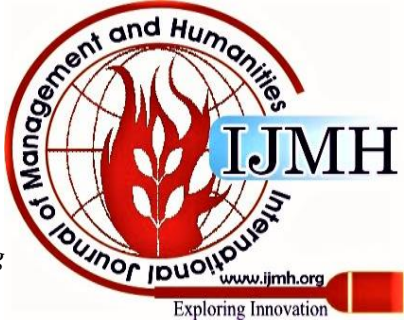


Determinants of Employees Outstanding Performance in Public Corporations: Strategic Human Resource Management Perspectives of Organisational Development and Sustainability

\begin{tabular}{llrrrr} 
& & 1 & 2 & 3 & 4 \\
\hline HLPRR & Pearson Correlation & 1 & & & \\
& Sig. (2-tailed) & & & & \\
& $\mathrm{N}$ & 300 & & & \\
EEEEM & Pearson Correlation & $1.000^{* *}$ & 1 & & \\
& Sig. (2-tailed) & .000 & & & \\
& $\mathrm{~N}$ & 300 & 300 & & \\
ERSOP & Pearson Correlation & $.866^{* *}$ & $.866^{* *}$ & 1 & \\
& Sig. (2-tailed) & .000 & .000 & & \\
& $\mathrm{~N}$ & 300 & 300 & 300 & \\
EIP & Pearson Correlation & $.866^{* *}$ & $.866^{* *}$ & $1.000^{* *}$ & 1 \\
& Sig. (2-tailed) & .000 & .000 & .000 & \\
& $\mathrm{~N}$ & 300 & 300 & 300 & 300 \\
\hline
\end{tabular}

**. Correlation is significant at the 0.01 level (2-tailed).

Table 3 shows that there is positive correlation between performance and engagement and also between staff engagement and rewards. It has been established that when high-levels of performance are recognised and rewarded appropriately, such act will result to the enhancement of employee motivation level which prompt the exhibition of pleasant attitude towards work. Further considerations are that, when employees are recognised for sustained outstanding performance, it also increases their determination to exhibit their creative acumen for effective job performance. Additionally, when employees are highly engage, their propensity to demonstrate commitment will be evident in the performance of their duties. In consideration to aforesaid, it is noteworthy that determining outstanding performance considerably reflect on the relationship between training and engagement, training and rewards, engagement and rewards and performance and rewards.

\section{CONCLUSION}

This study carefully assessed determining factors towards outstanding performance in organisational settings. As a result, it thoroughly reviewed pieces of literature which enabled the identification of gaps not addressed by previous researches on the subject matter. The study further employed primary data collection through the distribution of questionnaires to a sample units of 300 , which enabled the gathering of preliminary information that led to the discovery of facts, which facilitated the analysis, discussion and conclusion of the study. Data was analysed using descriptive statistics and correlation which was done with the aid of SPSS. Revealed facts shows that, determining outstanding performance in organisational setting requires consideration on the effective conduct of training and development, high employee engagement to ensure staff commitment and the provision of adequate financial and non-financial rewards. It is further emphasised that if such components are effectively managed, exhibiting outstanding performance will be assured. The relevance of aforementioned facts connotes that, organisations can only operate effectively if they consider the significance of building staff capacity, engaging employees to stimulate commitment and adequately rewarding institutions workforce to produce the required results that leads to organisational development and sustainability. In this regard, this study is considerably relevant to knowledge management specialists, human capital professionals, general management practitioners, business consultants and the three corporate institutions used as case studies. Future research direction may consider an increase in sample size or sample frame or may examine individual components from a wider spectrum of organisations operations. Alternatively, other methods could be used to discuss the subject matter from different perspectives.

\section{ACKNOWLEDGEMENTS}

I wish to acknowledge the contributions of management and staff of the Central Bank of Sierra Leone, the National Revenue Authority and the National Social Security and Insurance Trust for their unflinching support towards the gathering of primary data from their employees which facilitated the completion of this study. Appreciation goes to colleagues who facilitated the distribution and collection of questionnaires. Finally, I would like to extend my appreciation to colleagues at the School of Economics and Business administration in Chongqing University for the perusal of this manuscript's content that ensured the development of a standardised article for publication.

\section{REFERENCES}

1. Adams, M., \& Jiang, W. (2017). Do chief executives' traits affect the financial performance of risk-trading firms? Evidence from the UK insurance industry. British Journal of Management, 28(3), 481-501.

2. Adler, S., Campion, M., Colquitt, A., Grubb, A., Murphy, K., Ollander-Krane, R., \& Pulakos, E. D. (2016). Getting rid of performance ratings: Genius or folly? A debate. Industrial and Organizational Psychology, 9, 219-252. https://doi.org/10.1017/iop. 2015.106.

3. Armstrong Michael (2007), Employee Reward Management and Practice, (2nd Edition), Kogan Page Limited, United Kingdom

4. Armstrong Michael (2009), Armstrong's Handbook of Performance Management, (4th Edition), Kogan Page Limited, United Kingdom.

5. Armstrong M. (2010), Armstrong's Essential Human Resource Management Practice, A Guide to People Management, Kogan Page Ltd, London.

6. Anderson, J.R. (2002). Measuring Human Capital: Performance Appraisal Effectiveness. Paper presented at the Human Resource Track Midwest Academy of Management Conference. Kansas City: Missouri.

7. Babu, T. N., \& Reddy, G. S. (2013). Role of HRM Practices in Cement Industry. International Journal of Marketing, Financial Services \& Management
Research, $2(8), \quad 46-52$. Research, 2(8), 46-52. Retrieved

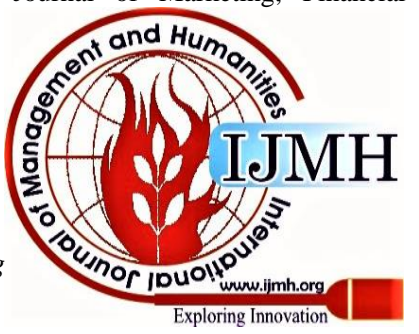


http://indianresearchjournals.com/pdf/ijmfsmr/2013/august/5.pdf

8. Banerjee, S., Prabhu, J. C., \& Chandy, R. K. (2015). Indirect learning: How emerging market firms grow in developed markets. Journal of Marketing, 79(1), 10e28.

9. Baumann, M. R., \& Bonner, B. L. (2017). An expectancy theory approach to group coordination: Expertise, task features, and member behavior. Journal of Behavioral Decision Making, 30, 407-419. https://doi.org/10.1002/bdm.1954.

10. Bauer, F., Matzler, K., \& Wolf, S. (2016). M\& A and innovation: The role of integration and cultural differences-A central European targets perspective. International Business Review, 25, 76-86.

11. Becker, B.E., Huselid, M.A. and Ulrich, D. (2001), The HR Scorecard. Linking People, Strategy and Performance. Harvard Business School Press.

12. Beninato, M., \& Ludlow, L.H. (2016). The functional gait assessment in older adults: Validation through Rasch modeling. Physical Therapy, 96(4), 456-469.http://dx. doi.org/10.2522/ptj.20150167

13. Berberoglu, A., Secim, H. (2015), Organizational commitment and perceived organizational performance among health care professionals: Empirical evidence from a private Hospital in Northern Cyprus. Journal of Economics and Behavioral Studies, 7(1), 64-71.

14. Bhavani SA, Sharavan and Arpitha (2015), A Study Effectiveness of Employee Engagement in Automobile Industry, International Journal of Economics \& Management Sciences, p 1-5

15. Blythe, J. (2014). Principles and practice of marketing. London, U.K.: Sage Publishing.

16. Boone, W.J., Staver, J.R., \& Yale, M.S. (2014). Rasch analysis in the human sciences (E-reader version). http://dx.doi.org/10.1007/978-94007-6857-4

17. Brian P. Browna, Mayoor Mohana, D. Eric Boydb (2017), Top management attention to trade shows and firm performance: A relationship marketing perspective, Journal of Business Research, Elsevier, p 1-11

18. Brown, T. C., O'Kane, P., Mazumdar, B., \& McCracken, M. (2019) Performance management: A scoping review of the literature and an agenda for future research. Human Resource Development Review, 18, 47-82. https://doi.org/10.1177/1534484318798533.

19. Brown M, et al. (2010). Consequences of the performance appraisa experience: Personnel Review, 39(3), 375-396

20. Bruggeman, W., Decoene, V. \& Everaert, P (2001) 'An empirical study of the impact of BSC-based variable remuneration systems on performance motivation of operating managers, Working Paper, Ghent University, Faculty of Economics and Business.

21. Bryson, A., Pendleton, A., \& Whitfield, K. (2013). The Changing Use of Contingent Pay at the Modern British Workplace. National Institute of Economic and Social Research, Discussion Paper No. 319

22. Bussin, M., \& Van Rooy, D.J. (2014). Total rewards strategy for multigenerational workforce in a financial institution. SA Journal of Human Resource Management/ SA Tydskrif vir Menslikehulpbronbestuur, 12(1), Art. \#606, 1-11. http://dx.doi.org/10.4102/sajhrm.v12i1.606

23. Callahan, D. (2004). The cheating culture: why more Americans are doing wrong to get ahead. Orlando, FL: Harcourt

24. Canos-Daros, L. (2013) An Algorithm to Identify the Most Motivated Employees. Management Decision, 51, 813-823. http://dx.doi.org/10.1108/00251741311326581

25. Cappelli, P., \& Conyon, M. J. (2018). What do performance appraisals do? ILR Review, 71, 88-116. https://doi.org/10.1177/0019793917698649 .

26. Cappelli, P., \& Tavis, A. (2016). The performance management revolution. Harvard Business Review, 94(10), 58-67.

27. Cartwright Roger (2003), Implementing Training and Development Strategy, Capstone Publishing Limited, United Kingdom

28. Casimir, G., Ngee Keith Ng, Y., Yuan Wang, K., Ooi, G. (2014), The relationships amongst leader-member exchange, perceived organizational support, affective commitment, and in-role performance:

29. Chandler M. Tamra (2016) How Performance Management Is Killing Performance, Berrett-Koehler Publishers, Inc., Oakland, CA.

30. Chay Hoon Lee and Norman T. Bruvold, (2003). „Creating value for employees: investment in employee development, Int. J. of Human Resource Management Vol.14 No. 6 p 981-1000.

31. Chris, A. (1999). Organizational learning. US: Blackwell Publisgers

32. Coens, T, and Jenkins, M (2002) Abolishing Performance Appraisals: Why they backfire and what to do instead, Berrett-Koehler, San Francisco.

33. Cokins Gary (2009), Performance Management, Integrating Strategy Execution, Methodologies, Risk, and Analytics, John Wiley \& Sons, Inc., Hoboken, New Jersey.

34. Collinson, C. and Parcell, G. (2001), Learning after doing Knowledge Management, Vol. 5, Issue 2.

35. [] Conyon, M. J., Hass, L. H., Peck, S. I., Sadler, G. V., \& Zhang, Z (2019). Do compensation consultants drive up CEO pay? Evidence from UK public firms. British Journal of Management, 30(1), 10-29

36. Davenport, T.H. and Glaser, J. (2002), Just-in-Time Delivery Comes to Knowledge Management. Harvard Business Review.

37. Demetrion, G. (2003). John Dewey's educational philosophy. Core concepts. Available at http://www.nald.ca.

38. Deming, W E (1986) Out of the Crisis, Massachusetts Institute of Technology Centre for Advanced Engineering Studies, Cambridge, MA

39. DeNisi, A. S., \& Murphy, K. R. (2017). Performance appraisal and performance management: 100 years of progress? Journal of Applied Psychology, 102, 421-433. https://doi.org/10.1037/apl0000085.

40. Dineen, B. R., \& Williamson, I. O. (2012). Screening-oriented recruitment messages: Antecedents and relationships with applicant pool quality. Human Resource Management, 51, 343-360

41. Dolores M. H. and Ernest C. W. (2018), Enhancing Teachers Performance through Training and Development in Ghana Education Service (A Case Study of Ebenezer Senior High School), Journal of Human Resource Management, 2018; 6(1): 1-8

42. Dresner H. [2008], Business Results Through Insight and Action, John Wiley \& Sons, Inc., Hoboken, New Jersey.

43. Fathi Vajargah, K. (2002). Training Needs Assessment: Models and Techniques. Tehran Press Yyzh.

44. Fisher S.G. (1997), The Manager's Pocket Guide to Performance Management, HRD Press, Inc. 22 Amherst Road Amherst, MA 01002 (800) 822-2801.

45. Getnet, B., Jebena, T., \& Tsegaye, A. (2014). The Effect of Employee's Fairness Perception on Their Satisfaction towards the Performance Appraisal Practices (A Case Study of University of Gondar). International Journal of Management and Commerce Innovations, 2(1), 174-210.

46. Giangreco, A., Carugati, A., Sebastiano, A., Tamimi, H. A., 2012: War outside, ceasefire inside: An analysis of the performance appraisal system of a public hospital in a zone of conflict. Eval Program Plann, 35, 1: 161-170. ISSN 0149-7189

47. Giumetti, G. W., Schroeder, A. N., \& Switzer, F. S., III (2015) Forced distribution rating systems: When does "rank and yank" lead to adverse impact? Journal of Applied Psychology, 100, 180-193. https://doi.org/10.1037/a0037191

48. Gladwell, M (2008) Outliers: The story of success, Allen Lane, London.

49. Goler, L., Gale, J., \& Grant, A. (2016). Let's not kill performance evaluations yet. Harvard Business Review, 94(11), 90-94.

50. Gomes-Mejia, L. R., Balkin, D.B and Cardy, R. L. (2012). Managing Human Resources. Prentice Hall

51. Grundy Tony and Brown Laura (2003), Developing the Individual, Capstone Publishing, 1RE United Kingdom.

52. Gubbi, S. R., Aulakh, P. S., \& Ray, S. (2015). International search behavior of business group affiliated firms: Scope of institutional changes and intragroup heterogeneity. Organization Science, 26(5), 1485-1501

53. Gupta, A., \& Upadhyay, D. (2012). Impact of effectiveness of performance management system on employee satisfaction and commitment. International Journal of Management, IT and Engineering, 2(7).

54. Hair, J. F., Jr., Hult, G. T. M., Ringle, C., \& Sarstedt, M. (2014). A primer on partial least squares structural equation modeling (PLSSEM). London: Sage.

55. Herhausen, D., De Luca, L. M., \& Weibel, M. (2018). The interplay between employee and firm customer orientation: Substitution effect and the contingency role of performance- related rewards. British Journal of Management, 29(3), 534-553.

56. Hayek, M., Thomas, C. H., Novicevic, M. M., \& Montalvo, D. (2016). Contextualizing human capital theory in a non-Western setting: Testing the pay-for-performance assumption. Journal of Business Research, 69, 928-935. https://doi.org/10.1016/j.jbusres.2015.06.039.

57. Horibe, F. (1999). Managing Knowledge Workers. Etobicoke, Ontario: John Wiley \& Sons Canada Limited

58. Ikramullah, M., Van Prooijen, J., Iqbal, M. Z., \& Ul-Hassan, F. S. (2016). Effectiveness of performance appraisal: Developing a conceptual framework using competing values approach. Personne Review, 45, 334-352 https://doi.org/10.1108/PR-072014-0164.

59. Iqbal, M. Z., Akbar, S., \& Budhwar, P. (2015) Effectiveness of performance

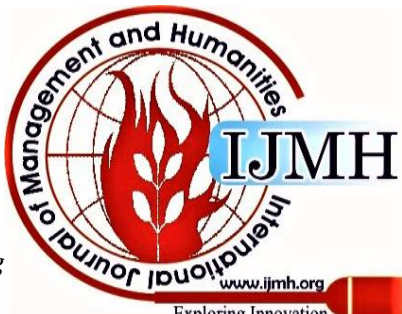



Determinants of Employees Outstanding Performance in Public Corporations: Strategic Human Resource
Management Perspectives of Organisational Development and Sustainability

appraisal: An integrated framework. International Journal of Management $\quad$ Reviews, $17, \quad 510$ 533.https://doi.org/10.1111/ijmr.12050.

60. Jehanzeb, K., Rasheed, A., \& Rasheed, M. F. (2013). Organizational Commitment and Turnover Intentions: Impact of Employee's Training in Private Sector of Saudi Arabia. International Journal of Business and Management, 8(8), 79-90. http://dx.doi.org/10.5539/ijbm.v8n8p79

61. Johnson, G., \& Connelly, S. (2014). Negative emotions in informal feedback: The benefits of disappointment and drawbacks of anger. Human Relations, 67, 1265-1290. https://doi.org/10.1177/0018726714532856.

62. Karkoulian, S., Assaker, G., \& Hallak, R. (2016). An empirical study of 360-degree feedback, organizational justice, and firm sustainability. Journal of Business Research, 69, 1862-1867. https://doi.org/10.1177/0018726715596802.

63. Kallio, K., Kallio, T. J., Tienari, J., \& Hyvönen, T. (2016). Ethos at stake: Performance management and academic work in universities. Human Relations, 69,

64. Kock, N. (2015). Common method bias in PLS-SEM: A full collinearity assessment approach. International Journal of eCollaboration, 11, 1-10. https://doi.org/10.4018/ijec.2015100101.

65. Kondalker V.G. (2007), Organisational Behaviour, New Age International (P) Ltd., Publishers, New Delhi.

66. Krausert Achim (2008), Performance Management for Different Employee Groups A Contribution to Employment Systems Theory, Springer-Verlag Berlin.

67. Kuvaas, B. (2006). Performance Appraisal Satisfaction and Employee outcomes; mediating and moderating roles of work motivation. International Journal of Human Resources Management. 17(3): $504-$ 522.

68. Lamba, S., \& Choudhary, N. (2013). Impact of HRM Practices on Organizational Commitment of Employees. International Journal of Advancements in Research \& Technology, 2(4), 407-423. Retrieved from http://www.ijoart.org/.

69. Lambert, M., Vero, J., \& Zimmermann, B. (2012). Vocational training and professional development: A capability perspective. International Journal of Training and Development, 16, 164-182. http://dx.doi.org/10.1111/j.14682419.2012.00402.x

70. Mackey, K. \& Johnson, G. (2000). The Strategic Management of Human Resources in New Zealand. Auckland: Irwin/McGraw-Hill.

71. Maley, J. F., \& Moeller, M. (2014). Global performance management systems: The role of trust as perceived by country managers. Journal of Business Research, 67, 28032810.https://doi.org/10.1016/j.jbusres.2012.08.003

72. Majumder, M. T. H. (2012). Human Resource Management Practices and Employees' Satisfaction Towards Private Banking Sector in Bangladesh, 2(1), 52-58. Retrieved from http://www.econjournals.com/

73. Mani, B. (2002). Performance appraisal systems, productivity, and motivation: A case study. Public Personnel Management. 31(19): 141159.

74. Mellahi, K., Frynas, J. G., \& Collings, D. G. (2016). Performance management practices within emerging market multinational enterprises: The case of Brazilian multinationals. The International Journal of Human Resource Management, 27, 876905.https://doi.org/10.1080/09585192.2015.1042900

75. Meneghel, I., Borgogni, L., Miraglia, M., Salanova, M., \& Martínez, I. M. (2016). From social context and resilience to performance through job satisfaction: A multilevel study over time. Human Relations, 69, 2047-2067. https://doi.org/10.1177/0018726716631808.

76. Merriman, K. K. (2017). Extrinsic work values and feedback: Contrary effects for performance and well-being. Human Relations, 70, 339-361. https://doi.org/10.1177/0018726716655391.

77. Michaels, E., H. Handfield-Jones, et al. (2001). The War for Talent. Cambridge, MA: Harvard Business School Press.

78. Miner, J. B. (2015). Organizational behavior 1: Essential theories of motivation and leadership. London, UK: Routledge.

79. Mitchelmore, S., \& Rowley, J. (2013). Growth and planning strategies within women-led SMEs. Management Decision, 51(1), 83-96.

80. Motro, D., \& Ellis, A. P. (2017). Boys, don't cry: Gender and reactions to negative performance feedback. Journal of Applied Psychology, 102, 227-235. https://doi.org/10.1037/apl0000175.

81. Muhammad Z. I., Saeed A., Pawan B., Syed. Z. A. S. (2019), Effectiveness of performance appraisal: Evidence on the utilization criteria, Journal of Business Research. Elsevier. https://doi.org/10.1016/j.jbusres.2019.04.035.

82. Mullins Laurie J. (2005), Management and Organisational Behaviour, (7th Edition), Pearson Education Limited, England. 709.https://doi.org/10.1177/0018726715596802.

83. Noe Raymond (2010), Employee Training and Development, (5th Edition), McGraw-Hill Companies, Inc, New York.

84. Obeidat, B. Y., Masa'deh, R., and Abdallah, A. B. (2014). The Relationships among Human Resource Management Practices, Organizational Commitment, and Knowledge Management Processes: A Structural Equation Modeling Approach. International Journal of Business and Management, 9(3), 9-26. http://dx.doi.org/10.5539/ijbm.v9n3p9.

85. Pakdel, R. (2004). Management and Leadership Training Organization (Vision System-Strategic).Tehran: the Moein Institute.

86. Pelin K. Selahattin K. Mert G. (2015). The Effects of Organizational Structures and Learning Organization on Job Embeddedness and Individual Adaptive Performance. 2nd Global Conference on Business, Economics, Management and Tourism, 30-31 October 2014, Prague, Czech Republic. Elsevier

87. Pollard, D. (2003). The future of knowledge management. Discussion paper. Available

http://blogs.salon.com/0002007/images/TheFutureofKnowledgeMana gement

88. Rae Leslie (2000), Effective Planning in Training and Development, Kogan Page Limited, United Kingdom.

89. Riaz, A., Idrees, R. N., \& Imran, A. (2013). Employees' Belief Regarding Training Benefits and Organizational Commitment: A Case in Banking Sector of Pakistan. Middle-East Journal of Scientific Research, 16(3),

310-318 http://dx.doi.org/10.5829/idosi.mejsr.2013.16.03.11671.

90. Rothwell William J. (2005), Beyond Training and Development, The Ground breaking Classic on Human Performance Enhancement, (2nd Edition), American Management Association, New York.

91. Rudman, R. (2003). Human Resources Management in New Zealand. Auckland: Pearson Education New Zealand Limited.

92. Rumizen, M. (2001). The Complete Idiot's Guide to Knowledge Management. New York: Alpha Books.

93. Scheer August-Wilhelm, Jost Wolfram, Heß Helge \& Kronz Andreas (2006), Corporate Performance Management ARIS in Practice, Springer-Verlag Berlin.

94. Schulz, M., and Jobe, L. A. (2001). Codification and tacitness as knowledge management strategies: an empirical exploration. Journal of High Technology Management, 12(1): 139-165.

95. Selvarajan, T. T., Singh, B., \& Solansky, S. (2018). Performance appraisal fairness, leader member exchange and motivation to improve performance: A study of US and Mexican employees. Journal of Business Research, 85, 142-154. https://doi.org/10.1016/j.jbusres.2017.11.043

96. Seyyed Abolfazl Miria, Nur Naha Abu Mansorb, Zahra Chasempourc, Roya Anvarid (2013), Staff Organization Training: Designing, Stages, and Methods, International Conference on Innovation, Managemen and Technology Research, Elsevier

97. [] Shortliffe, E., L. Perreault, et al., eds. (2001). Medical Informatics: Computer Applications in Health Care and Biomedicine. New York: Springer.

98. Shrivastava, S., Pazzaglia, F., Sonpar, K., \& McNamara, P. (2015). Unpacking the effect of exploration during environmental uncertainty: Evidence from the information technology sector. Canadian Journal of Administrative Sciences, 33(1), 36e49

99. Singh, S., Tabassum, N., Darwish, T. K., \& Batsakis, G. (2018) Corporate governance and Tobin's Q as a measure of organizational performance. British Journal of Management, 29(1), 171-190.

100. Skovoroda, R., \& Bruce, A. (2017). Shifting the goalposts? Analysing changes to performance peer groups used to determine the remuneration of FTSE 100 CEOs. British Journal of Management, 28(2), 265-279.

101. Skyrme, D. (2002). What's next for knowledge management? Update Entovation International News. Availableathttp://www.skyrme.com/updates/u57_f1.htm

102. Soltani, I. (2006). Interaction, and Assessment of Effectiveness of Training in learning Organizations. Isfahan: Arkan Dansh Publisher.

103. Sreejesh S. et al (2014), Business Research Methods, An Applied Orientation, Springer

104. Stone, R. (2002). Human Resources Management. 4th Edition. Brisbane: Wiley

105. Studt, T. (2003). Knowledge management is key to

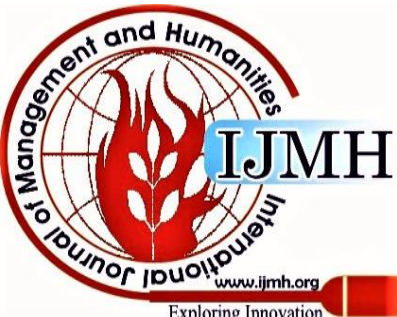


improving drug R \& D cycles. R \& D, 45(4): 18.

106. Swathi, B. (2014). A Comprehensive Review on Human Resource Management Practices. IMPACT: International Journal of Research in Business Management, 2(9), 21-28.

107. Xhavit I.b., Enis M., Naim M. (2018), Using Management by Objectives as a performance appraisal tool for employee satisfaction. Future Business Journal. https://doi.org/10.1016/j.fbj.2018.01.001

108. Vajehe, E. (2006). Organizational learning based on creation a learning organization. Journal of Knowledge Management.

109. Venkatesan, R. (2017). Executing on a customer engagement strategy. Journal of the Academy of Marketing Science, 45(3), 289-293.

110. Verweire Kurt and Berghe Lutgart Van Den (2004), Integrated Performance Management A Guide to Strategy Implementation, SAGE Publications Ltd, London

111. Vimala Kadiresan1, Mohamad Hisyam Selamat1, Sugumaran Selladurai1, Charles Ramendran SPR \& Ramesh Kumar Moona Haj Mohamed (2015), Performance Appraisal and Training and Development of Human Resource Management Practices (HRM) on Organizational Commitment and Turnover Intention, Asian Social Science, $\mathrm{p}, 1-15$

112. Vinesh (2014), Role of Training \& Development in an Organizationa Development, International Journal of Management and International Business Studies, pp. 213-220

113. Vohra, N., \& Seethapathy, S. (2014), State of B2B event marketing. Retrieved from http:// www.regalix.com/wpcontent/uploads/2014/11/State-of-B2B-Event-Marketing- Survey Report.pdf (Report)

114. Vomberg, A., Homburg, C., \& Bornemann, T. (2015). Talented people and strong brands: The contribution of human capital and brand equity to firm value. Strategic Management Journal, 36(13), 2122e2131

115. Wang, X., Ma, L., Zhang, M. (2014), Transformational leadership and agency workers organizational commitment: The mediating effect of organizational justice and job characteristics. Social Behavior and Personality: An International Journal, 42(1), 25-36

116. Williams, R.S. (2002). Managing Employee Performance: Design and Implementation in Organisations. London: Thompson Learning.

117. Winerip, M. (2013). 35 Indicted in test scandal at Atlanta schools New York Times, A1.

118. Xhavit I.b., Enis M., Naim M. (2018), Using Management by Objectives as a performance appraisal tool for employee satisfaction. Future Business Journal. https://doi.org/10.1016/j.fbj.2018.01.001

119. Yıldız, S., Baştürk, F., Boz, İ.T. (2014). The effect of leadership and innovativeness on business performance. Procedia-Social and Behavioral Sciences, 150, 785-793

120. Youngsang Kim and Robert E. Ployhart (2013), The Effects of Staffing and Training on Firm Productivity and Profit Growth Before, During, and After the Great Recession, American Psychological Association, No. 3, 361-389

121. Yousefi M, Behboudi M R and Zarghamifard M 2016 Examining the Impact of Organizational Structure on Career Anchors of Employees in Public and PrivateOrganizations International Business Management 10(11) pp 2177-2184

122. Zafar Gul (2015), Impact of Employee Commitment on Organizational Development, FWU Journal of Social Sciences, p 1-8

123. [] Zeffane, R., Zeffane, R., Bani Melhem, S. J., \& Bani Melhem, S. J. (2017). Trust, job satisfaction, perceived organizational performance and turnover intention: A public-private sector comparison in the United Arab Emirates. Employee Relations, 39(7), 1148-116.

124. Zhao, P., \& Liu, Y. (2015). Evolutionary game of cooperation between cultural and creative enterprises from both sides of the Taiwan strait: From the perspective of anthropology. Anthropologist, 21(1e2), 61e70

125. Života Radosavljević, Vesna Ćilerdžić4 and Milan Dragić (2017), Employee Organizational Commitment, Faculty of Business Economics and Entrepreneurship International Review, p 1-9 the School of Economics and Business Administration - Chongqing University in China. He is a graduate of Universidad Empresarial de Costa Rica with a Master of Business Administration in Strategic Management. He also holds Master of Science in Corporate Management and Bachelor Science (Honors) in Entrepreneurship and Human Capital Management. He has extensive knowledge in Human resource management practice and his research areas are Strategic Human Resource Management, Organisational Behaviour, Performance Management, Management theory and Practice, Business Communication, Employee Relations and Negotiations, Entrepreneurship, Total Quality Management and Corporate Governance and Leadership.

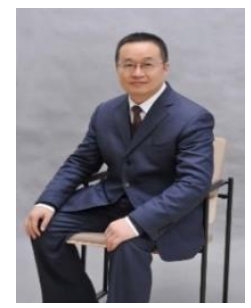

Professor Feng Ming is a Professor of Management at Chongqing University in China. He holds a $\mathrm{PhD}$ in Industrial and Organizational Psychology from Zhejiang University, Master's degree in General Psychology and a Bachelor of Education from Southwest University in China. He is currently the Head of the Department of Management at the School of Economics and Business Administration - Chongqing University. He has published numerous articles and authored many books on Human Resource Management, Industrial Psychology, Organisational Behaviour andKnowledge Management. His research areas are: HumanResource Management, Organisational Behaviour and Applied Psychology.

\section{AUTHORS PROFILE}

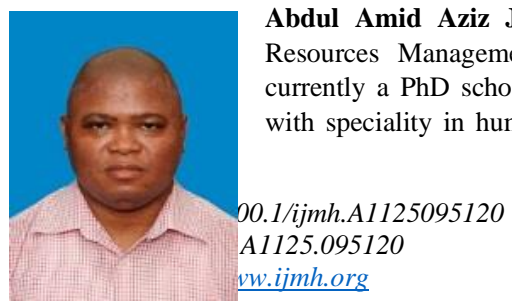

Published By:

Blue Eyes Intelligence Engineering

\& Sciences Publication

(C) Copyright: All rights reserved.

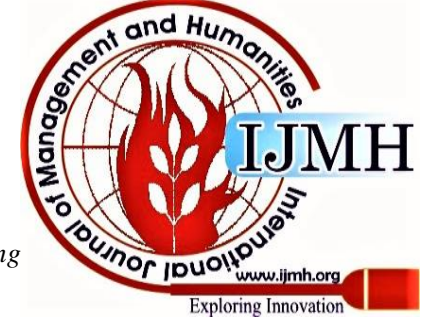

Exploring Innovation 